\title{
Effect of Low Light Stress on Physio-Biochemical, Grain Yield and Quality Traits of Rice
}

\author{
Aradhana Dhruw* and Arti Guhey \\ Department of plant physiology, College of agriculture Raipur (IGKV, Raipur), India \\ *Corresponding author
}

\section{A B S T R A C T}

\section{Keywords \\ Rice, RILs, low light, yield, quality \\ Article Info \\ Accepted: \\ 20 May 2018 \\ Available Online: \\ 10 June 2018}

Low light is one of the most important environmental factors that determine the basic characteristics of rice growth and development. The selected twenty five adopted varieties are grown in Kharif 2016 under both normal and low light condition. The result were found that biochemical parameters such as grain starch content and total carbohydrate content (TCC) was decreased under low light condition and, nitrogen content in leaf was increased at flowering stage, protein content in grain was also affected by low light as well as grain yield and quality of rice. The genotype DXD (124)-17-192 possessing higher grain protein content and grain yield.

\section{Introduction}

Rice (Oryza sativa L.) is the staple food of more than half of the world population. Solar radiation is a limited during the monsoon season and in July and August, the average daily duration of bright sunshine in only 2-3 hours per day. Lower incidence of solar radiation coupled with fluctuating light intensity due to overcast sky sun during the wet season (Feb. to Nov.) is one of the major constraints for rice production in eastern India. Light intensity is a basic characteristic asset, which controls morphogenesis and production in plants. It has a major role in photosynthesis, photoperiodism, and photonasty. In fact, agriculture can be defined as the exploitation of solar radiation with the help of water and nutrients (Fageria, 2013). The Light intensity is among essential prerequisites for plant development, advancement, survival, and yield efficiency (Wang, 2013). Under low light during the grain-filling stage decreased supply of carbohydrates to grains as well as a decrease in starch synthase activity in grains, which directly inhibits grain filling and enhances the occurrence of chalky rice ( $\mathrm{Li}$ et al., 2005).

\section{Materials and Methods}

The experiment was conducted in the Department of Plant physiology and at RRL, college of agriculture, Indira Gandhi Krishi Vishwavidylaya, Krishak Nagar Raipur (C.G.) during kharif 2015-16 and 2016-17. The experiment was laid out in split plot design and consisted of 139 RILs lines and 17 
released varieties from IGKV, Raipur and 4 varieties from NRRI under normal condition and shade net (70:30) condition (low light condition) and net shade condition had provided at 40 days after transplanting.

\section{Results and Discussion}

\section{Starch content}

Starch content decreased (by $26 \%$ ) under low light (Table1). normal light condition, it ranged from 0.645 to 0.970 whereas under low light stress starch content varies from 0.435 to 0.970. Under normal light significantly recorded maximum starch content as compared to low light treatment. The variety IGKV-R-1 (Rajeshwari) took maximum starch content under low light stress and the genotype DXD (124) 17-191 exhibit higher shade index percent. It may be due to the low light inhibit the translocation of assimilates from source organs to sink organ (grains). Umemoto et al., (1976) found that activities of ADPGPPase and starch branching enzymes were significantly correlated with starch accumulation rate and starch synthesis and they are key enzymes during starch synthesis course in rice grains. The starch synthesis amount declined under the low light condition. Similar findings were also reported by Nayak et al., (1978) and Tashiro et al., (1980).

\section{Total carbohydrate content (TCC)}

Significant differences were noticed among the treatment in relation to carbohydrate content. Under normal light condition, it ranged from 0.425 to 0.730 whereas under low light stress carbohydrate content ranged from 0.270 to 0.500 . Under low light significantly recorded lowest total carbohydrate content as compared to normal light condition. It is reduced $42 \%$ under low light stress. Jaldubi was found maximum total carbohydrate content 0.730 and 0.500 under both normal light and low light condition respectively and the variety IBD-1 exhibit higher shade index percent. Low light reduced total carbohydrate contents in leaf and grain significantly. The reduction in TCC in leaf by reduced light is due to impairment of dry matter production at PI, and even more reduction of it after flowering for partitioning into the developing grains at harvest (Janardhan et al., 1980).

\section{Grain protein content}

Under normal light condition it ranged from 7.28 to 10.22 whereas under low light stress grain Protein content ranged from 5.25 to 8.21. Significant differences were noticed among the treatment in relation to grain Protein content. Grain protein content was reduced (by 27\%) under low light as compare to normal. DXD (124)-17-192 was found maximum total grain protein content 10.22 and 8.21 under both normal light and low light condition respectively and the variety IGKVR-2 (Maheshwari) exhibit higher shade index percent. Similar result was reported by Basanta Barmudoi and Bhagawan Bharali (2016) grain protein contents, under normal light exceeded its value at low light treatment.

\section{Nitrogen content in leaf at $50 \%$ flowering}

Significant differences were noticed among the different light treatments in relation to nitrogen content. Under normal light condition it ranged from 0.37 to 1.24 while under low light stress nitrogen content ranged from 0.62 to 1.71.Under normal light significantly recorded minimum nitrogen content as compared to low light treatment at $50 \%$ flowering. The genotype $\operatorname{DXD}(124)-1-10$ (1.24) and DXD(124)-17-191 (1.71) was exhibit maximum nitrogen content in leaf under both normal and low light conditions respectively and the variety IGKV-R-2 (Maheshwari) exhibit higher shade index percent. 
Table.1 Effect of low light stress on starch content, Carbohydrate content, Grain Protein content, Nitrogen content and grain yield

\begin{tabular}{|c|c|c|c|c|c|c|c|c|c|c|c|c|c|c|c|c|}
\hline \multirow[t]{2}{*}{ SN. } & \multirow[t]{2}{*}{ Name of genotype } & \multicolumn{3}{|c|}{ STARCH CONTENT } & \multicolumn{3}{|c|}{ CARBOHYDRATE CONTENT } & \multicolumn{3}{|c|}{ GRAIN PROTEIN CONTENT } & \multicolumn{3}{|c|}{ NITROGEN CONTENT IN LEAF } & \multicolumn{2}{|c|}{ GRAIN YIELD } & \multirow[b]{2}{*}{$\begin{array}{l}\text { shade } \\
\text { index }\end{array}$} \\
\hline & & NL & $\mathbf{L} \mathbf{L}$ & $\begin{array}{l}\text { shade } \\
\text { index }\end{array}$ & NL & $\mathbf{L L}$ & $\begin{array}{l}\text { shade } \\
\text { index }\end{array}$ & NL & $\mathbf{L L}$ & $\begin{array}{l}\text { shade } \\
\text { index }\end{array}$ & NL & $\mathbf{L L}$ & shade index & NL & $\mathbf{L L}$ & \\
\hline 1 & $\mathrm{DXD}(124) 1-10$ & 0.91 & 0.65 & 71.82 & 0.72 & 0.27 & 37.06 & 8.97 & 6.31 & 70.35 & 1.24 & 2.18 & 175.81 & 642.45 & 303.70 & 47.27 \\
\hline 2 & DXD(124)1-12 & 0.87 & 0.57 & 65.90 & 0.60 & 0.20 & 33.33 & 9.59 & 7.32 & 76.33 & 0.71 & 1.05 & 147.89 & 501.50 & 313.90 & 62.59 \\
\hline 3 & $\mathrm{DXD}(124) 2-22$ & 0.76 & 0.58 & 76.16 & 0.58 & 0.23 & 39.13 & 9.22 & 6.99 & 75.81 & 0.82 & 1.26 & 153.66 & 461.60 & 241.05 & 52.22 \\
\hline 4 & DXD(124)3-28 & 0.91 & 0.67 & 73.48 & 0.73 & 0.28 & 38.62 & 8.69 & 6.32 & 72.73 & 0.57 & 0.67 & 117.54 & 493.70 & 205.65 & 41.65 \\
\hline 5 & DXD(124)5-72 & 0.92 & 0.73 & 79.78 & 0.66 & 0.21 & 31.82 & 9.34 & 7.09 & 75.91 & 0.72 & 0.95 & 131.94 & 509.45 & 293.85 & 57.68 \\
\hline 6 & DXD(124)9-89 & 0.90 & 0.63 & 69.44 & 0.65 & 0.43 & 66.15 & 7.58 & 5.51 & 72.69 & 0.63 & 1.18 & 187.30 & 439.50 & 253.65 & 57.71 \\
\hline 7 & DXD(124)9-91 & 0.90 & 0.74 & 82.22 & 0.67 & 0.38 & 56.39 & 8.64 & 5.94 & 68.75 & 0.67 & 1.19 & 177.61 & 459.90 & 312.65 & 67.98 \\
\hline 8 & DXD(124)11-133 & 0.88 & 0.53 & 60.23 & 0.59 & 0.21 & 35.90 & 9.03 & 5.98 & 66.22 & 0.60 & 1.07 & 178.33 & 575.60 & 383.60 & 66.64 \\
\hline 9 & $\mathrm{DXD}(124) 13-148$ & 0.88 & 0.71 & 81.14 & 0.66 & 0.36 & 54.20 & 8.45 & 5.50 & 65.09 & 0.49 & 0.93 & 189.80 & 400.75 & 302.20 & 75.41 \\
\hline 10 & DXD(124)15-164 & 0.66 & 0.52 & 78.79 & 0.53 & 0.13 & 23.81 & 8.90 & 6.35 & 71.35 & 0.63 & 1.03 & 163.49 & 832.30 & 300.95 & 36.16 \\
\hline 11 & DXD(124)15-168 & 0.65 & 0.44 & 67.44 & 0.52 & 0.08 & 14.56 & 9.86 & 7.32 & 74.24 & 0.77 & 1.38 & 179.22 & 468.80 & 289.05 & 61.66 \\
\hline 12 & $\mathrm{DXD}(124) 16-179$ & 0.82 & 0.56 & 68.29 & 0.73 & 0.29 & 39.31 & 7.28 & 5.24 & 71.98 & 0.59 & 1.03 & 174.58 & 534.15 & 323.70 & 60.60 \\
\hline 13 & DXD(124)17-191 & 0.84 & 0.72 & 85.71 & 0.63 & 0.23 & 36.51 & 10.21 & 7.88 & 77.18 & 0.71 & 1.28 & 180.28 & 730.20 & 365.90 & 50.11 \\
\hline 14 & DXD(124)17-192 & 0.87 & 0.55 & 63.22 & 0.76 & 0.30 & 38.82 & 9.98 & 8.12 & 81.36 & 0.88 & 1.37 & 155.68 & 727.00 & 399.25 & 54.92 \\
\hline 15 & $\operatorname{DXD}(124) 17-193$ & 0.85 & 0.52 & 60.95 & 0.69 & 0.15 & 21.17 & 10.11 & 7.34 & 72.60 & 0.73 & 1.35 & 184.93 & 709.55 & 395.80 & 55.78 \\
\hline 16 & $\mathrm{DXD}(124) 17-210$ & 0.88 & 0.67 & 76.57 & 0.74 & 0.27 & 36.49 & 8.21 & 6.08 & 74.06 & 0.53 & 0.92 & 173.58 & 695.55 & 385.25 & 55.39 \\
\hline 17 & $\mathrm{DXD}(124) 21-262$ & 0.85 & 0.64 & 75.74 & 0.74 & 0.52 & 70.07 & 8.52 & 6.36 & 74.65 & 0.59 & 1.12 & 189.83 & 616.30 & 328.00 & 53.22 \\
\hline 18 & SWARNA SUB-1 & 0.88 & 0.63 & 72.00 & 0.70 & 0.43 & 60.71 & 8.51 & 6.35 & 74.62 & 0.57 & 1.04 & 182.46 & 490.60 & 394.05 & 80.32 \\
\hline 19 & SAMLESHWARI & 0.75 & 0.58 & 77.85 & 0.57 & 0.24 & 42.48 & 7.64 & 5.56 & 72.77 & 0.56 & 1.00 & 178.57 & 473.40 & 296.35 & 62.60 \\
\hline 20 & IBD-1 & 0.91 & 0.72 & 79.56 & 0.66 & 0.55 & 83.97 & 8.85 & 6.43 & 72.66 & 0.67 & 1.29 & 192.54 & 553.10 & 311.75 & 56.36 \\
\hline 21 & IGKV-R-1 (RAJESHWARI) & 0.97 & 0.76 & 78.35 & 0.69 & 0.22 & 31.16 & 9.90 & 7.05 & 71.21 & 0.68 & 1.21 & 177.94 & 509.40 & 373.40 & 73.30 \\
\hline 22 & IGKV-R-2(MAHESHWARI) & 0.81 & 0.67 & 82.61 & 0.64 & 0.26 & 40.16 & 9.04 & 7.89 & 87.28 & 0.59 & 1.15 & 194.92 & 510.75 & 273.70 & 53.59 \\
\hline 23 & JALDUBI & 0.90 & 0.72 & 79.44 & 0.73 & 0.30 & 41.10 & 10.22 & 8.21 & 80.33 & 0.83 & 1.55 & 186.75 & 450.80 & 311.45 & 69.09 \\
\hline 24 & ISD-1 & 0.70 & 0.56 & 80.58 & 0.57 & 0.20 & 35.40 & 9.28 & 6.16 & 66.38 & 0.65 & 1.25 & 192.31 & 339.30 & 186.35 & 54.92 \\
\hline \multirow[t]{7}{*}{25} & INDIRA SONA & 0.91 & 0.56 & 61.33 & 0.72 & 0.30 & 40.97 & 9.00 & 6.05 & 67.22 & 0.70 & 1.32 & 188.57 & 345.95 & 233.75 & 67.57 \\
\hline & Treatmental Mean & 0.844 & 0.624 & & 0.656 & 0.279 & & 8.997 & 6.612 & & 0.69 & 1.19 & & 538.86 & 311.16 & \\
\hline & & CD & SEM & & CD & SEM & & CD & SEM & & CD & SEM & & CD & SEM & \\
\hline & Treatment(T) & 0.188 & 0.01 & & 0.262 & 0.015 & & 1.772 & 0.099 & & 0.353 & 0.02 & & 6.55 & 0.37 & \\
\hline & Varieties(V) & 0.065 & 0.023 & & 0.051 & 0.018 & & 0.573 & 0.201 & & 0.425 & 0.149 & & 22.37 & 7.84 & \\
\hline & V X T & 0.14 & 0.052 & & 0.17 & 0.073 & & N/A & 0.493 & & N/A & 0.098 & & 31.82 & 1.82 & \\
\hline & T X V & 0.144 & 0.033 & & 0.194 & 0.029 & & N/A & 0.296 & & N/A & 0.207 & & 31.2 & 10.87 & \\
\hline
\end{tabular}

$\mathrm{NL}=$ normal light, $\mathrm{LL}=$ low light, $\mathrm{N} / \mathrm{A}=$ non-significant, $\mathrm{CD}=$ critical difference, $\mathrm{SEM}=$ standard error of mean 
Fig.1 Effects of normal light (NL) and low light (LL) on starch content of rice (Oryza sativa L.)

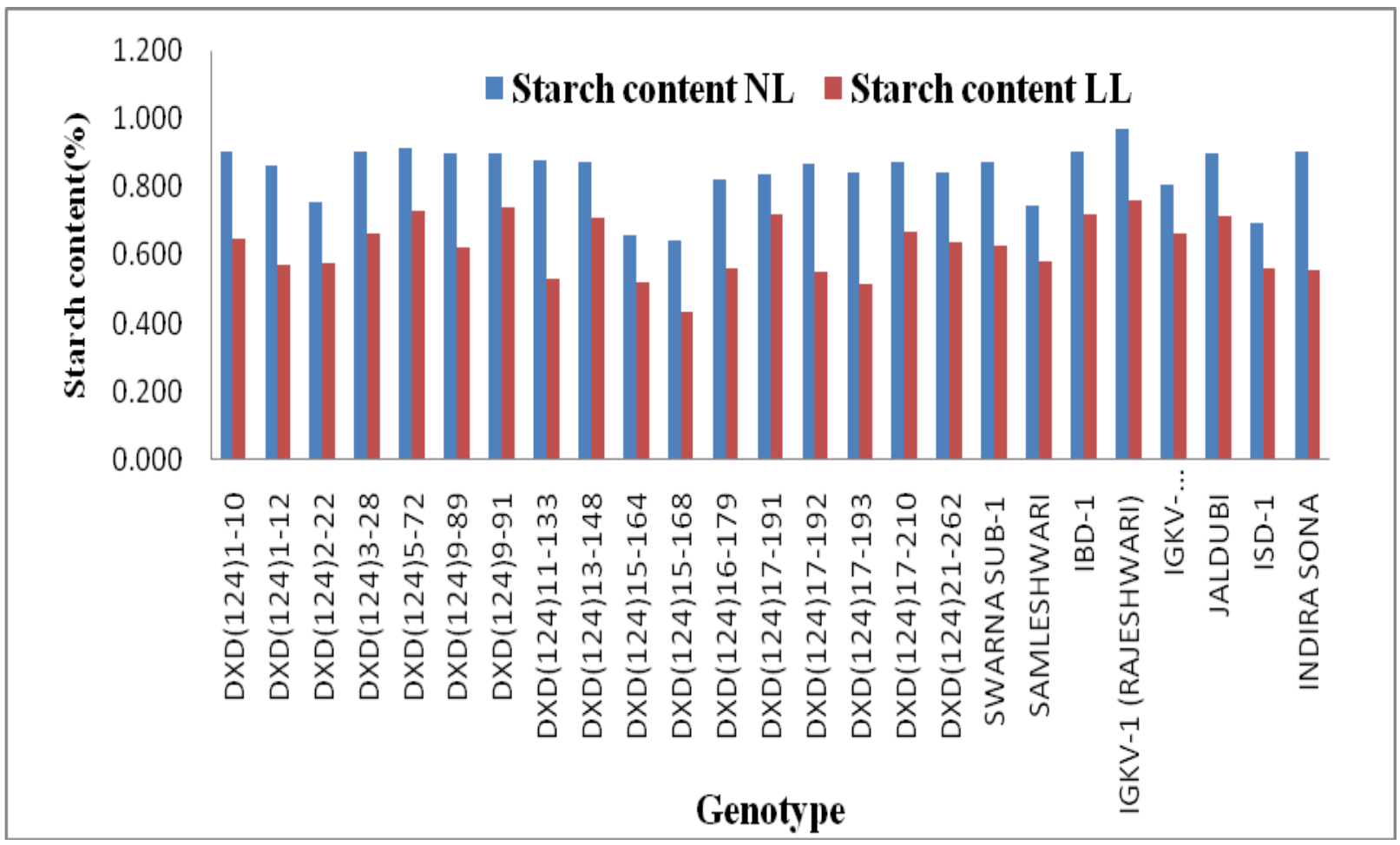

Fig.2 Effects of normal light (NL) and low light (LL) on total carbohydrate content of rice (Oryza sativa L.)

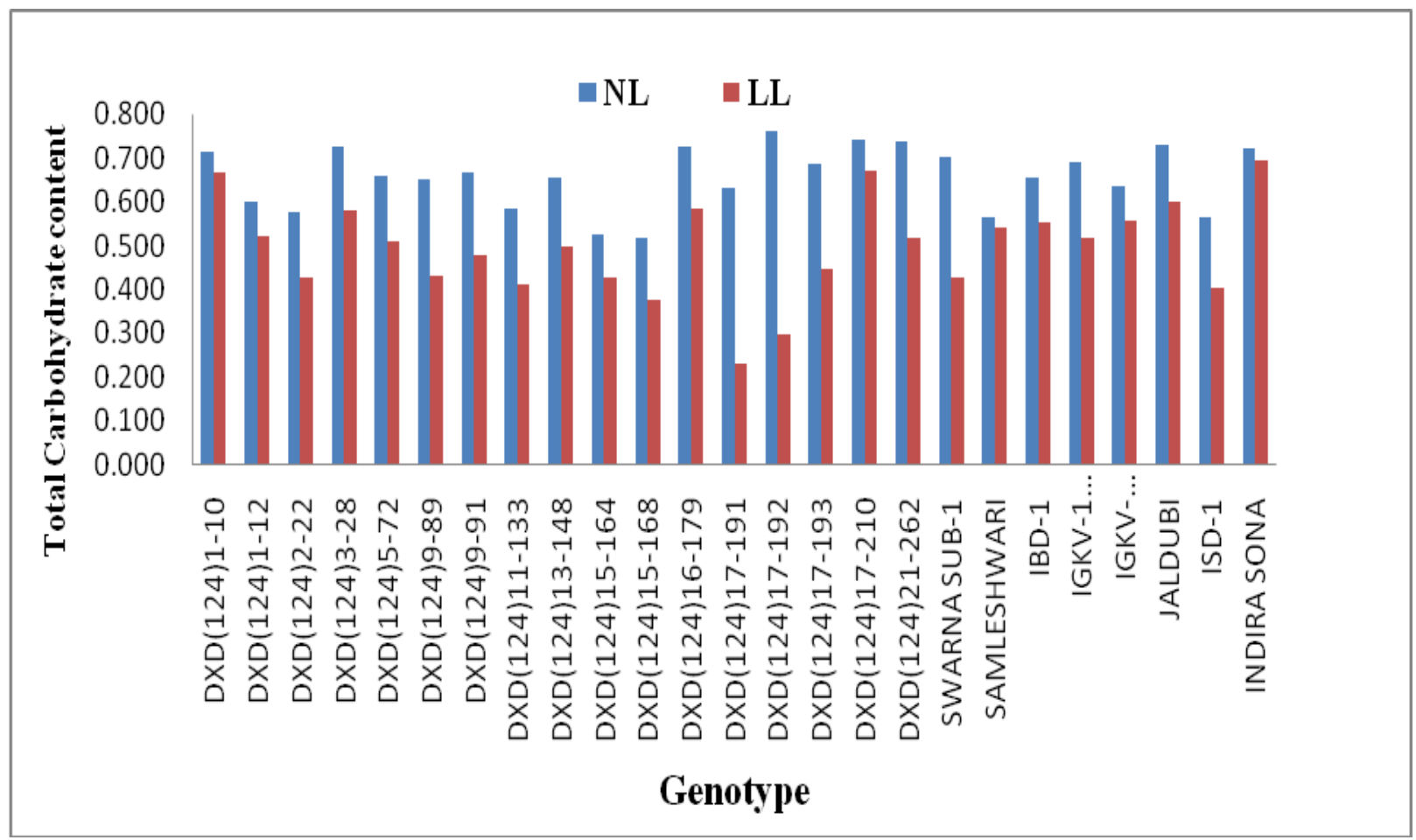


Fig.3 Effects of normal light (NL) and low light (LL) on grain protein content of rice (Oryza sativa L.)

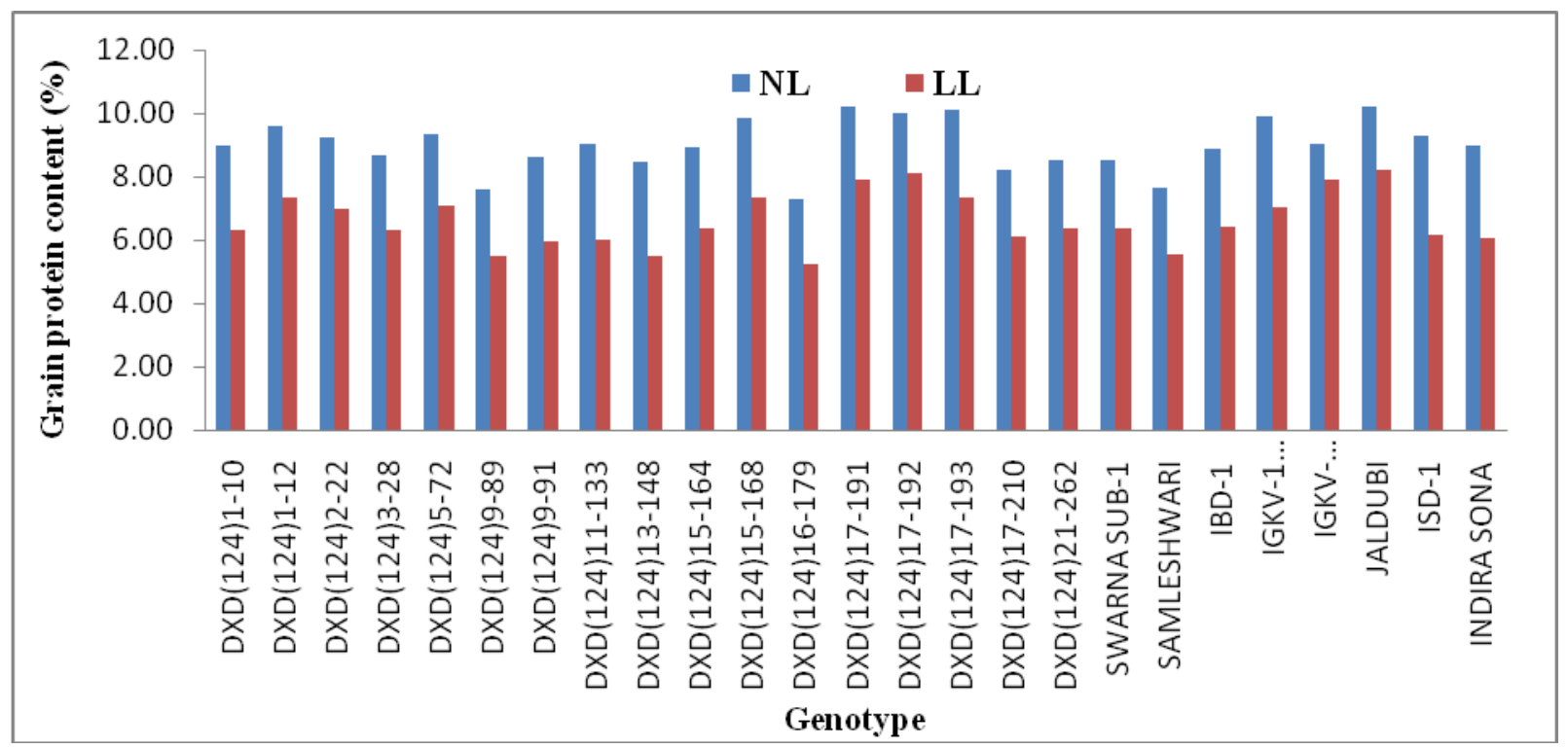

Fig.4 Effects of normal light (NL) and low light (LL) on nitrogen content in leaf of rice (Oryza sativa L.)

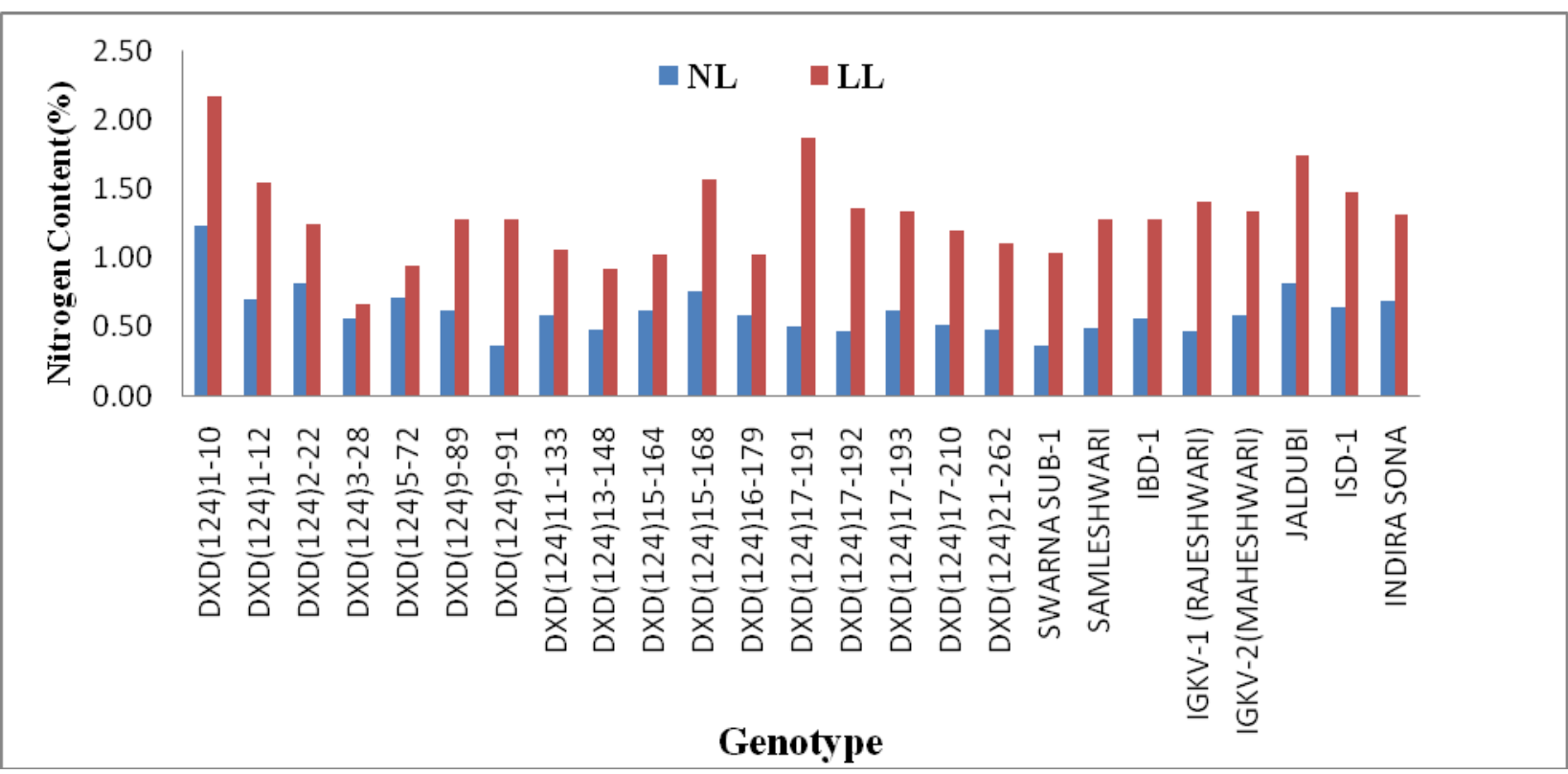

At $50 \%$ flowering stage, $\mathrm{N}$ content in leaf increase in low light significantly. Sahu and Murty (1976) also opined that nitrogen uptake at flowering is relatively high in wet season and is reduced only after flowering. So, plants growing under lower light always show higher nitrogen content in shoot and panicle at flowering. It has consequence on the high sterility of grains in plants under lower light regimes. Greater accumulation of nitrogen, especially soluble $\mathrm{N}$ occurs in panicle during anthesis, and at a juvenile stage of grain 
development. Low light intensity influences the amount of nitrogen utilized for grain production (Pandaraju et al., 1976).

\section{Grain Yield}

Significant differences were noticed among the treatments in relation to grain yield. Under normal light condition, it ranged from 339.30 to $832.30 \mathrm{~g}$ whereas under low light stress grain yield ranged from 186.35 to $399.25 \mathrm{~g}$. G

rain yield, was decrease under low light as compare to normal light. Highest grain yield was found in DXD (124)-17-192. It was decreased $42 \%$ under low light stress and the variety Swarna Sub-1exhibit higher shade index percent. Grain yield was decreased significantly under low light as compare to normal light.

Deng et al., (2009) reported that low light causes impairment of the net photosynthetic rate as well as lower dry matter accumulation and sink capacity in rice plants and these significantly reduces the number of filled grains and 1000 grain weight, thereby leading to decrease grain yield.

Lower incidence of solar radiation is one of the major constraints for rice production in India.

Low light intensity was reduced the yield and quality traits of rice. The genotype DXD (124)-17-192 was exhibit higher grain yield and it also has higher grain protein content. This genotype was performing better under low light stress.

\section{Acknowledgement}

This study was financially supported by Krishi Vishwavidylaya DRS, IGKV, Raipur and Rajiv Gandhi National Fellowship (RGNF), New Delhi.

\section{References}

Barmudoi, B. and Bharali, B. 2016. Effects of light intensity and quality on physiological changes in winter rice (Oryza sativa L.) International Journal of Environmental \& Agriculture Research (IJOEAR), 2(3)

Deng, F., Wang, L., Yao, X., Wang, J.J. and Ren, W.J. 2009. Effects of different growing- stage shading on rice grainfilling and yield. J. Sichuan Agri. Univ. 27(3): 265-269.

Fageria, N.K. 2013. Mineral nutrition of rice. CRC press, Taylor and Francis Group.Boca Raton.

Janardhan, K. V., Murty, K S. 1980. Effect of low light during vegetative stage on photosynthesis and growth attributes in rice. Ind J Plant Physiol, 23(2): 156162.

Li, T., Ohsugi, R., Yamagishi, T., Sasaki, H. 2005. Effects of weak light on rice starch accumulation and starch synthesis enzyme activities at grain filling stage. Chin J Rice Sci, 19(6): 545-550.

Nayak, S. K., Janardhan, K.V. and Murty, K.S. 1978. Photosynthetic efficiency of rice as influenced by light intensity and quality. Ind J Plant Physiol., 21(1): 4852.

Panda Raju A and Deb A.R. 1976 Note on the influence of sunlight intensity on the productivity of Jaya and WP-130 varieties of rice. Indian Journal of Agricultural Science. 4: 489-497.

Sahu, G. and Murty, K.S. 1976. Seasonal influence of on dry matter production, nitrogen uptake and yield in rice varieties.Indian Agric. 20: 43-50.

Tashiro, T. and Ebata, M. 1975. Studies on white belly rice kernel: III. Effect of ripening conditions on occurrence of white belly kernel. Proc. Crop Sci. Soc. Jpn., 44(1): 86. 
Umemoto T, Nakamura Y, Ishikura N. 1976. Effect of grain location on the panicle on activities involved in starch synthesis in rice endosperm. Phytochemistry, 36: 843-847
Wang, L., Deng, F., Ren, W.J., and Yang, W.Y., 2013.Effects of Shading on Starch Pasting Characteristics of Indica Hybrid Rice (Oryza sativa L.). Plos one 8(7): 68220

\section{How to cite this article:}

Aradhana Dhruw and Arti Guhey. 2018. Effect of Low Light Stress on Physio-Biochemical, Grain Yield and Quality Traits of Rice. Int.J.Curr.Microbiol.App.Sci. 7(06): 2889-2895. doi: https://doi.org/10.20546/ijcmas.2018.706.340 